\title{
EMI and the 'Pre-heritage' Period Film
}

\author{
Claire Monk
}

\section{Abstract:}

First coined in the UK in the early 1990s as a new label for an ostensibly new, post-1979, kind and cycle of period cinema, the 'heritage film' is now firmly established as a widely used term and category in academic Film Studies. Although the heritage film's defining features, ideological character and ontological coherence would remain debated, its status as a 'new' category hinges (self-evidently) on the presumption that the films of post-1979 culturally English heritage cinema marked a new departure and were clearly distinct from their pre-Thatcher-era precursors. Yet, paradoxically, the British period/costume films of the preceding decade, the 1970s, have attracted almost no scholarly attention, and none which connects them with the post-1979 British heritage film, nor the 1980s cultural and industry conditions said to have fostered the heritage film with those of the 1970s. This article pursues these questions through the prism of Britain's largest film production and distribution entity throughout 1970-86, EMI, and EMI's place as a significant, and sustained, but littleacknowledged force in British period film production throughout that time. In so doing, the article establishes the case for studying 'pre-heritage' period cinema. EMI's period film output included early proto-heritage films but also ventured notably wider. This field of production is examined within the broader terrain of 1970s British and American period cinema and within wider 1970s UK cinema box-office patterns and cultural trends, attending to commercial logics as well as genre and the films' positioning in relation to the later heritage film debates.

Keywords: heritage film, period historical and costume genres, EMI Films, 1970s British cinema, retro and cultures of revival, Agatha Christie, Lord Brabourne, G. W. Films, Christine Edzard, Richard Goodwin, Sands Films.

Introduction: the case for considering the 'pre-heritage' film

The 'heritage film' first emerged as a label and set of arguments in the UK in the early 1990s - the term itself was coined by Andrew Higson (1993) - and fast came to dominate Film Studies discourse around recent cinematic representations of the past: particularly, though not exclusively, in the British context, and initially with specific reference to post-1979 British cinema and its place in the cultural and political 'battle for Britain' (Fuller 1988: 62) under 
the Thatcher/ite Conservative governments of 1979-90. Although the heritage film's defining features, ideological character and ontological coherence - as an ostensibly new cycle or genus of costume film/period literary adaptation, and even, by some accounts, a 'new genre' (Vincendeau 2001: xvii) - would remain much-debated, as a widely applied term and category it has nonetheless entered 'the common sense of film culture' (Higson 1996: 232). This 'common sense' hinges, however, on certain basic assumptions: that the cycle of films most commonly identified as exemplary of post-1979, culturally English 'heritage cinema' are, first, indeed a coherent cycle and, second, clearly distinct from their pre-Thatcher era period film precursors.

This claim to cyclical and historical distinctiveness is entwined with the label's explicitly critical, even pejorative, origins (see Monk 2011: 2-3) within an ideologicalaesthetic critique of the films which was tangibly shaped by the cultural-political battles and tensions of their time: not merely around 1980s British cinema and its negotiations of Englishness and class, but around the leveraging of these 'images for sale' (Elsaesser 2006) in the international image markets and the Thatcher government's wider commodification of heritage as expressed in the National Heritage Acts of 1980 and 1983. Indeed, the initial heritage film critique drew substantially on Patrick Wright's (1985) and Robert Hewison's (1987) trenchant investigations of the rise of the heritage industry, and emerged in parallel with wider cross-disciplinary work on the interconnectedness of 'the heritage/enterprise couplet' (Corner and Harvey 1991: 45) and its functions in the post-1979 market-worshipping neoliberal new order. However, the critique's insinuation of a neat, quasi-official relationship between the heritage film, heritage industry and official agendas was, in most cases, at odds with the films' empirical creative and production origins, and spawned a blinkered, reductive and othering account of the films themselves, their alleged textual workings and their presumed audience appeal. (For a fuller outline of the critique's context, conjectures and limitations, see Monk 2011: 10-19; Monk 2002.) As Bélen Vidal would observe retrospectively: 'Implicit (and sometimes explicit) in the discussion [lay] the politics of taste that inform the reception of the heritage film and its unspoken status as the "bad object" par excellence in 1990s academic film studies' (2012: 121).

Self-evidently, the heritage film gained discursive ground as a 'new' category only because it was perceived as a new departure, distinct from what came before. Yet, paradoxically - in contrast with the wealth of work on the contemporary costume film which 
followed the heritage film debates - there remains a lack of scholarly attention to costume films/period literary adaptations of the preceding decade, the 1970s; and no work which attempts to connect, compare or contrast the post-1979 British heritage film with its immediate precursors, nor the cultural and socio-economic conditions of the 1980s which fostered the heritage film with those of the 1970s. Taking my cue from cultural and social historians, and, indeed, wider disciplines, including the rigorous work undertaken by Laurel Forster and Sue Harper in their British Culture and Society in the 1970s, there are sound reasons to frame this subject with reference to the 'long 1970s', 'beginning with the so-called revolutions of 1968 and [in the UK context] ending with the rise of Thatcher in 1979' (2010: $6)$.

One, which lies beyond the scope of this article, is that the scholarly inattention to the heritage film's relation to its precursors stretches back to the marked stylistic and tonal shifts in 1960s British period cinema wrought by the British New Wave directors, as well as by the more widely discussed Ken Russell. A second reason, widely ignored by film scholars and directly pertinent to my discussion, is that several of the cultural conditions and fascinations often cited as explanatory factors for the rise and appeal of the heritage film (and equally salient to the taste for wider 'nostalgia' and retro-styled genres) were already evident in Britain by the mid-to-late 1960s and early 1970s. One of the few contextualising studies in this area has been published by the art historian Elizabeth Guffey, who usefully notes the cultural rise at that time of an 'unsentimental' nostalgia (2006: 10). The heterogeneous aesthetic, material and consumer manifestations of this were empirically abundant, but have since been buried by selective cultural memory and therefore widely ignored. Third, the EMI conglomerate's entry into film production, too, belongs to the long 1970s: EMI's completed acquisition of the Associated British Picture Corporation (ABPC) and ABPC's Elstree Studios, and the appointment of Bryan Forbes as EMI Films' first Head of Production, all date from 1969 (Moody 2018: 11-13).

Cinematically and contextually, then, the severance of the now-extensive work on post-1979 (and contemporary) British period cinema from consideration of its 1970s and 1960s precursors suppresses a consideration of continuities or differences between the 'preheritage' and heritage decades, whether at the site of production and personnel, styles and themes, or the taste formations of audiences. There has, of course, been valuable work by film historians on specific landmark British historical films from the 1960s (and less often the 
1970s) - for example, Hall (2002); Chapman (2005); Chapman (2009) - as well as consideration of the 1960s and 1970s period films of key figures such as David Lean (Williams 2016) or Ken Russell (Van Eecke 2015) within studies of their directorial oeuvres. But, by definition, such history-on-film and auteur-focused work does not encompass the full genre and production spectrum of British period screen fictions, and particularly not in their less esteemed modes: the long-denigrated costume film (Harper 1994; Cook 1996), and any film deemed guilty of proto-heritage nostalgia or excesses of 'unmotivated' period style. British period films of the 1970s are further marginalised by their production during a decade of crisis which "until very recently, [remained] an "unknown" decade in British cinema history' (Moody 2018: 3). More curiously, they have remained marginal in the wave of new scholarship on 1970s British cinema published since 2008 (Shail 2008; Newland 2010; Harper and Smith 2013), perhaps because the decade's repute for 'low-culture' genres, sexploitation, representational excesses and censorship controversies has continued to guide scholars' preoccupations.

In an important exception directly pertinent to this article, Sarah Street's chapter for Shail's collection analysed the cycle of all-star, spectacular Agatha Christie period adaptations produced by EMI from 1974 to 1982 with Lord Brabourne's companies G. W. Films and Mersham Productions. Street makes a case for characterising this, at first hugely successful, formula as 'heritage crime', and demonstrates its importance 'in establishing screen conventions that television drew upon' once 'the explosion of popular television adaptations featuring Miss Marple and Poirot' superseded big-screen Christie pictures (2008: 106). However, the particular traits in these films that Street identifies as heritage in fact exemplify the tensions between heritage and a wider, earlier and at times clashing terrain of period-film styles, modes and production contexts that I want to explore further in this article. In this context, my coinage and use of the term 'pre-heritage' has an intentional duality and openness, seeking to accommodate both similarity and difference. Period films of the 1970s may be only temporally pre-heritage, displaying avant la lettre heritage film or proto-heritage traits in a pre-1980s decade (as Street argues of the Christie cycle); or they may be 'preheritage' in the second sense that their style, mode or sensibility demonstrate subtle - or blatant - differences from the later heritage film. In reality, consideration of the period films of the pre-heritage 1970s entails an ongoing negotiation of both tendencies, in line with Paul Newland's broader observation that 'British cinema of the 1970s might be characterized by two things - fragmentation and transformation' (2010: 16). 
EMI as under-the-radar period-film producer: 1970s proto-heritage cinema and beyond

The Journal of British Cinema and Television special issue on EMI Films provides a timely opportunity to pursue these questions through the specific prism of 'the largest film production and distribution company in Britain' between 1970 and its eventual demise in 1986 (Moody 2018: 1), and through EMI's place as a significant but little-acknowledged force in British period film production during that period. As Paul Moody notes, EMI's role in the production, finance and release of many of the key works of 1970s and 1980s British cinema across all genres had been (prior to his 2018 monograph) 'recorded only marginally, as footnotes in autobiographies or general histories of British cinema' (ibid.: 1-2). It is, therefore, no surprise if EMI's significance as the producer, co-financer or distributor of a diverse spectrum of period films has similarly escaped attention. There are, however, further reasons for this neglect.

As a conglomerate which had entered film production explicitly as 'a potential goldmine' (ibid.: 12) during what would prove to be the dying years of Britain's twentiethcentury studio system, EMI differed markedly from the artisanal, independent, 'cultural' filmmaking model which would deliver most of the prominent successes of 1980s to 1990s heritage cinema - exemplified by younger companies like Goldcrest, or the longerestablished, proudly independent, transnational Merchant Ivory Productions partnership frequently with the support of Channel 4 Films/Film on Four. It was in EMI's nature as a business that it 'lacked an easily definable identity ... not being associated with a single genre' (ibid.: 2), and throughout the 1970s the company was more prolific in the production of lowbrow, big-screen TV spin-offs (one of the struggling 1970s British film industry's success stories: see Garvey 2010) than in 'quality' genres. Indeed, the tiny number of auteurist British-originated projects within EMI's period film roster - only Joseph Losey's The Go-Between (1971), and Dreamchild (1985), which was directed by Gavin Millar from an original script by Dennis Potter, can be thus classified - and the documented creative interference and/or insensitive handling that these projects suffered (see Moody 2018: 64-7, 197) confirm EMI as a firmly producer-led outfit with (in these cases) little concern for artistic autonomy or authorial vision. For a study of pre-heritage period film trends, however, this very eclecticism, and EMI's positioning as an overtly commercial enterprise which produced and released period films alongside 'low' popular genres in a notoriously 
unpromising decade, are precisely why EMI's period film output is of interest.

Forbes's opening slate for EMI, announced in December 1969, included two films, both set in the late-Victorian to Edwardian era at the very start of the twentieth century, which in themselves decisively cement EMI's contribution to a canon of British period cinema: The Railway Children (1970), the best-known adaptation of Edith Nesbit's 1905 children's novel, and Losey's collaboration with Harold Pinter on The Go-Between, adapted by Pinter from L. P. Hartley's 1953 novel. Both films' pre-World War I narratives, care in production and costume design, uses of English rural locations, unshowy quality of performances and sensitive adaptation of literary sources appear to place them close to what is today perceived as heritage cinema. Yet, as with many - or even most - later heritage films, the relationship of both texts to conservative notions of heritage is and remains open to contestation, in ways which transcend the early-1970s climate both films spoke to on their initial release. The Railway Children's benevolent Edwardian charm is the work of a socialist author: Nesbit was a founder of the Fabian Society. Its plot concerns three middle-class children moved to the country by their mother because their father has been imprisoned, falsely accused of spying, in an echo of the 1894-1906 Dreyfus Affair in France; before he is released, one episode of the book, and film, has the family helping a persecuted, pre-1917, Russian socialist exile.

Hartley's first-person novel The Go-Between, famed for its opening statement - 'The past is a foreign country; they do things differently there' (1953:1) - deals directly with the workings of time and traumatic memory: its narrator/protagonist, Leo Colston (Dominic Guard), pieces together his suppressed memories of events in the summer of 1900 when he was thirteen. Losey and Pinter's film forensically details the agonies of the adolescent Leo as a perpetual class outsider amid the alienating, purposeless rituals of the 1900 English countryhouse aristocracy, a milieu which the film presents from Leo's perspective. At the onset of the 1990s heritage film debates, The Go-Between's class critique and restless landscapes led it to be cited and praised as a counterexample to the supposed ideological perniciousness of the 1980s heritage film. Yet in these precise respects, Losey's film is not so very distant from, for example, James Ivory's supposedly heritage adaptation of E. M. Forster's witheringly socially critical (and surprisingly funny) gay novel Maurice (1987). Moreover, while the classconsciousness of The Go-Between feels intensely attuned to the mood of long-1970s Britain, Losey's film project had in fact been gestating since the first half of the 1960s. 
While the Forbes productions confirm the presence of a British proto-heritage cinema from the start of the 1970s, EMI's period film output is noteworthy for venturing wider, and for its sustained place in EMI production throughout the 1970s and into the 1980s, under successive Heads of Production (Forbes 1969-71; Nat Cohen 1971-6; Michael Deeley and Barry Spikings following EMI's May 1976 acquisition of British Lion; Spikings 1978-82 following Deeley's departure; and Verity Lambert 1982-5). This output spanned a gamut of genres and forms. Within these, a number of pre-heritage trends and commercial impetuses can be discerned, as can an uneven and at times uneasy balance between the formulaic and the innovative.

In the remainder of this article I shall explore these trends and tensions, and the place of EMI's period film productions within the broader terrain of 1970s pre-heritage British and American period cinema, within a framework that maps and situates this output within wider UK cinema box-office patterns and trends during the 1970s. This discussion will elaborate on the key genres and modes of period cinema which were evident, or emergent, in EMI's output from the 1970 s to the early 1980 s, with attention paid to commercial logics as well as to the films' relationship to notions of heritage cinema or other period genres. The resulting account shows that EMI Films' contributions to period film production ventured significantly beyond the proto-heritage Victoriana/Edwardiana of the company's early/Forbes years, including early, hybrid, instances of other genres which would emerge more fully from the 1980s onwards alongside responsiveness to 1970s-specific trends. The proto-heritage strand nonetheless occupies a central place in EMI's legacy for later 1980s-90s British period cinema - and heritage film-making teams - to which I return in my conclusion.

EMI's period films at the 1970s British box office: the 'pre-heritage' place and_formation of period genres

In the first half of the 1970s, in particular during the period of Forbes's and then Cohen's leadership, EMI period films featured consistently within the UK Top 10 or Top 20 cinema box-office titles of their year, competing alongside EMI's abundant British TV sitcom spinoffs, the James Bond and Disney franchises, miscellaneous US releases, and historical and costume films produced by other studios (Smith 2013: 269-74). The regular appearance of EMI, and other, period films - and, moreover, period films of more than one genre - in the 
UK box-office charts testifies to their success with audiences in the pre-heritage decade, but also poignantly illustrates the broader 1970s cinema exhibition context faced by these films in an era of severe difficulties for the sector and precipitous audience decline.

Thus in 1971, the two most timeless exemplars of the 'family entertainment' favoured by Forbes (Moody 2018: 13,27), The Railway Children and the enchanting, virtually unique, live-action Victorian-costume ballet film The Tales of Beatrix Potter (1971, released in the US as Peter Rabbit and the Tales of Beatrix Potter), reached sixth and eighth places respectively at the UK box office, bracketed by EMI's TV comedy spin-offs On The Buses (1971) and Up Pompeii (1971) at second and ninth respectively, the latter refashioned for the big screen as an AA-certificated sex comedy. In 1972, The Go-Between (poorly marketed by EMI) reached eighteenth place at the UK box office, in the company of EMI's Steptoe \& Son (1972) at sixth place and Mutiny on the Buses (1972) at nineteenth. 1972 was a year of strong period-film competition: The Go-Between was outstripped at the UK box office by Ken Russell's X-rated, heavily cut The Devils (1971) at fifth place; three lavish period epics registered as British but backed by US studios: Columbia's Nicholas and Alexandra (1971) at eighth, MGM's Ryan's Daughter (1970) at ninth, and Universal's Mary, Queen of Scots (1971) at eleventh; and the Columbia-distributed war/adventure biographical drama Young Winston (1972), directed by Richard Attenborough and based on Winston Churchill's 1930 memoir My Early Life.

Two further period films released by EMI in the UK in 1972 did not reach the year's box-office charts. The first was Ken Russell's complex, highly stylised The Boy Friend (1971), EMI's first release under the seven-year EMI-MGM partnership it had signed in 1970 (Moody 2018: 45-7). Described by Adrian Garvey (2010) as an 'anti-musical', it is simultaneously a backstage musical, set in a 1920s English seaside town; a pastiche of a pastiche (the company are staging Sandy Wilson's titular 1950s musical set on the 1920s French Riviera); an experiment in narratives nested within and commenting upon narratives; a giddying virtuoso exercise in retro style; and a star vehicle for the British model Twiggy.

The second was Henry VIII and His Six Wives (1972), notable as virtually the only traditional historical drama EMI would produce. It fitted the company's commercial logic, and was favoured by Cohen, because it was a TV spin-off, adapted - or, more accurately, enlarged and re-orientated - from BBC-TV's critically acclaimed, enormously successful six- 
play mini-series The Six Wives of Henry VIII (1970), with Keith Michell reprising his BAFTA- and Emmy-award-winning performance as the monarch. However, a strategy suited to EMI's TV sitcom spin-offs destined for domestic audiences had flaws, seemingly overlooked by the contemporary trade press as well as by Cohen, when applied to the BBC's 'quality' historical/costume dramas and classic serials produced during the 1970s 'Golden Age' of British television drama. Despite the studio-bound limitations of these productions (discussed in Bragg 2015; Monk 2015: 7-11), the BBC's Henry VIII was 'event' television in its own right, and its global sales confirmed the BBC's pre-eminence in the genre. The landmark success, high profile and global exportability of the BBC mini-series proved, however, to be the film's undoing, not least in its anticipated US market. By the time EMI's shoot began in October 1971, the BBC productions had already debuted on CBS television in the US, in addition to being repeated more than once on the BBC in the UK, and it would receive further, repeated television exposure in America in the Public Broadcasting Service's Masterpiece Theatre strand, which had launched in January 1971. Anglo-EMI's Henry VIII stands as a high-quality production, of both historiographic and cinematic interest in its own right (see Chapman 2005: 261-8), and its trade press reviews presumed its BBC origins would secure its commercial success. Variety called it "large-scaled yet "intimate" ... A beautifully crafted epic [which] should ride the crest of popularity currently enjoyed by such historical items capsuling pictures and personages of British history' ('Hawk.': 1972a). However, by the time the film belatedly reached US cinemas in October 1973, its US distributor, LeavittPickman, found it necessary to announce in Variety that 'though Keith Michell repeats his role as the oft-married, bumptious monarch, [this] is not ... the same film as the recently played-off US TV production, a BBC-TV import' (Anon.: 1973).

The Boy Friend's heightened Roaring Twenties/Art Deco style and sets, in contrast, were attuned to a highly marketable trend, the post-counterculture Art Deco revival, which by the late 1960s had permeated UK and North American style and consumer culture across fields from graphic design and typography to fashion as well as film. Post-classical American cinema had begun to exhibit a burgeoning fascination with Jazz Age and Prohibition-era retro styles and stories from Arthur Penn's 1967 Bonnie and Clyde onwards. By the early 1970s, Barbara Hulanicki's legendary Kensington boutique, Biba, provided and sold an immersive retail and lifestyle experience amid a decadent collision of fin-de-siècle, William Morris and Art Nouveau styles. In contrast with 1980s heritage aesthetics, this new, youthful fascination with old styles had countercultural origins and was promiscuously heterogeneous: 
psychedelic-Edwardian graphic art (from Alan Aldridge to Terry Gilliam) and Hammer Victoriana, antique fashion and 'Art Nouveau fever' (Guffey 2006: 8) were all part of the mix. A very few years after The Boyfriend, Art Deco set design and costume - by then, mainstream - would prove central to the aesthetic of EMI's most profitable period-film franchise, the Agatha Christie adaptations of 1974-82.

By 1973-4, the top-performing period film productions at the UK box office across all genres and nationalities point to further generic and societal shifts, and hint at attendant shifts in audience tastes, which can also be discerned in EMI's period film releases from 1973 onwards. In 1973, the top period film at the UK box office was the musical Cabaret (1972) at seventh place; and, in 1974, Universal's The Sting (1973) at first, The Three Musketeers: The Queen's Diamonds (1973) - a transnationally co-produced caper distributed by Fox, with British stars Oliver Reed and Michael York as two of the musketeers - at fourth, and Paramount's The Great Gatsby (1974) at seventh. Amy Sargeant's commentary (2005) on the Musketeers captures significantly the playfulness of a further key pre-heritage historical film mode which was both prevalent and popular in British cinema from the 1960s onwards, beginning with the transatlantic success of Tony Richardson's Tom Jones (1963), and which epitomised precisely the 'inauthenticity' against which 1980s heritage cinema appeared to react. The fact that Sergeant can credibly apply the present author's later $(1995 ; 2001)$ concept of the post-heritage film (which is self-consciously not heritage) to this much earlier example points to both the heterogeneity of period film styles and - of particular pertinence here - their cyclical reactivity. As Sargeant states, the film's handling of history is fanciful rather than analytical ... Like the historical Carry Ons, it is self-consciously a confection rather than a deconstruction. But it equally offers an alternative (on wet Sunday afternoons) to the more 'respectful' adaptations serialised on BBC1 in my childhood. One might suggest that it constitutes 'post-heritage' (a term coined by Claire Monk) prior to the advent of heritage film proper in the 1980s. ... The Three Musketeers gave us Raquel Welch ... and swordsmen dressed as French nuns. ... There are gestural nods in the direction of historical verisimilitude, in scripting, settings (large-patterned wallpaper being fashionably styled in the 1970s by David Hicks et al.), 'costume frippery and what-not', instruments of torture ... and a Real Tennis match between Aramis and Porthos. (2005: 279) 
EMI's two 1973 UK period film successes as distributor and/or producer are incoherently diverse, but in ways which signal innovation and responsiveness to new markets. In ninth place at the UK box office, Lady Caroline Lamb (1972), written and (for the first time) directed by David Lean's illustrious screenwriter Robert Bolt as a star vehicle for Bolt's wife Sarah Miles (the titular lead in Lean's epic historical romance Ryan's Daughter, released the previous year), was a UK/Italian co-production - rare, and noteworthy, at that time released by MGM-EMI in the UK, and the fifth most popular historical film of any nationality at the UK box office in the 1970s (Smith 2013: 266). Lamb, born Caroline Ponsonby in 1785, was an Anglo-Irish aristocrat, Gothic novelist and fascinating historical figure: a niece of Georgiana, Duchess of Devonshire (the subject of Saul Dibb's 2008 historical-biographical drama The Duchess, starring Keira Knightley) and also related to Sarah Ponsonby, one half of the male-dressing lesbian couple known as the 'Ladies of Llangollen'. Lamb herself wore male garb and revelled in outrageous behaviour, providing a role well suited to Miles's own febrile, unrestrained trademark acting style.

The film was announced under the working title Lamb (reflecting its subject's preference for being addressed either by surname only or as 'Caro'), and there are signs that it may have been conceived as a more radical project than is evident in the final outcome. Lamb is popularly best known for her love affair with Lord Byron and for coining the description of him as 'mad, bad and dangerous to know'. Bolt's film makes the affair its core focus, casting Richard Chamberlain - 'at his prettiest' in the estimation of Gay News (Seligman 1972) - as Byron, and Jon Finch as Lamb's seemingly long-suffering politician husband, William Lamb. However, the relationship is portrayed as only briefly a passionate meeting of minds, and more protractedly as a one-sided tragic romance from which Lamb seemingly never recovers. This depiction is reductive in relation to the biographical facts, and while Miles's striking performance elicits deep sympathy, we witness her suffering as externalised spectacle, while her interiority remains, from a twenty-first-century feminist perspective, unsatisfactorily opaque.

The film's gushing contemporary reviews provide interesting insights into (male) critics', and the industry's, perhaps limited expectations of a female-centred historical biodrama in the early years of second-wave feminism, their grasp of 'women's lib', and their assumptions about female audience appeal - or 'distaff attention', to use Variety's term. George Melly in the Observer (1972) found the film an 'undeniably enjoyable' guilty 
pleasure but felt compelled to namedrop 'Mesdames Greer and Millett'. Variety praised Bolt's " "feel" or affinity for the femme psyche' but without denting the assumption that film directors and screenwriters are male, and opined that Bolt's directorial debut was

that relative rarity, a lushly, unabashedly romantic - yet tastefully executed - tale that you relish ... [but which also] rings a number of contemporary bells, both emotional and intellectual ... His tragic heroine, a controversial free thinker of the early British 1800s, has obvious parallels with present-day (achieved) femme emancipation ... Irrational or not, there'll be few distaffers unable to identify with one or another of the title character's ultimately instinctive, romantic moves which carry more than a trace of women's lib. ('Hawk.' 1972b)

EMI's other period-film hit at the 1973 UK box office, in tenth place, just below Lady Caroline Lamb, was aimed firmly at the domestic market and could scarcely be more different, including in its calculated appeal to a different 'distaff' demographic. That'll Be The Day (1973) was the first of two low-budget star vehicles for the Plaistow-born, working-class British pop star and hugely popular heart-throb David Essex, followed by a sequel, Stardust (1974), which remained in the UK box-office charts for two consecutive years - at seventeen in 1974 and nine in 1975. Scripted by journalist Ray Connolly, both films originated with Sandy Lieberson's and David Puttnam's company Goodtimes Enterprises and had Gavrik Losey as associate producer. Of the two, only That'll Be The Day, opening in the immediate post-war 1940s and set centrally in the late 1950s, is strictly a period film. (Its sequel, Stardust, opens narratively in the mid-1960s but makes no discernible effort at period style.) Both films are of significant interest as instances of EMI part-funding projects originating with one of the smaller (and, in this case, maverick) production companies which would typify the British film production landscape by the 1980s; and as an ingenious formula, strategically marketed and funded by innovative means. By Justin Smith's account, because EMI's Nat Cohen was unwilling to provide the full - very low - budget of $£ 288,000$, 'Puttnam agreed a deal with the American record label Ronco to part-finance the film in return for an action-packed soundtrack' (2008: 74). (More accurately, Ronco was an 'as-seenon-TV' gadget company for which compilation albums were one of its many product lines.)

That'll Be The Day holds further importance, however, as an early - if rough-andready - specifically British prototype for a new period film genre, distinct from heritage, which would be finessed a few years later in The Who's Quadrophenia (1979) and which 
would become more prevalent in British cinema from the late 1980s onwards, and even more prevalent post-2000: the pop culture/music retro film, set in a very recent past and nostalgically styled. It simultaneously stands as an early example of a wider field of British retro dramas and biopics - not always pop cultural - which began to gain ground in the 1980s and which have commonly been claimed by the heritage film's critics as a more 'democratic' alternative in terms of their social class focus and subjects. In post-classical and contemporary American cinema, this genre is usually termed the 'nostalgia film' (for a study, see Sprengler 2009). Andrew Higson closed his original critique of the heritage film by noting another group of contemporary British costume dramas [sic] dealing with the more recent past ... These films concentrate on the everyday lives and memories of “ordinary people" ... to some extent democratizing the genre and offering a rather different range of narrative pleasures and identifications. The converse of this, however, is that their representation of the past remains in a conservationist mode, such that even the mise-en-scène of ordinariness delights the eye. (Higson 2006:108).

That'll Be The Day is recognisably of this retro genre - still to be identified in 1973 yet at least one of its characteristics confirms its pre-heritage difference from later, 1980s, British retro films: its mise-en-scène, wider production design and cinematic style lack the 'conservationist mode', or at least do not bother to sustain it consistently. In a further preheritage indicator, its star/casting strategies (here, the use of British rock and pop stars in downbeat 'everyday' roles: the Beatles' Ringo Star, 1950s English rock'n'roller Billy Fury and The Who's Keith Moon alongside Essex) take a certain precedence which works against full audience immersion in the period diegesis even though the latter is rendered naturalistically. Indeed, the primacy of star personae, star performance styles and the star as box-office attraction over unobtrusive 'period' acting emerges as a wider tendency in EMI's 1970 s period films across various genres.

Furthermore, while James Leggott discusses That'll Be the Day in the context of social realism and notes the plot's echoes of the 'angry young man' narrative trope of the early-1960s British New Wave films, in the 1970s socio-economic and cinematic context, his identification of That'll Be The Day as a 'consciously backward-looking [film]' (2008: 96) suggests stasis rather than nostalgia. The film follows its protagonist, Jim McLean (Essex) from state-school sixth form - where his rebellion, banal and trope-ish, consists of throwing away his chance of a place at university - to a directionless existence in casual jobs (initially, 
deckchair attendant) in, as Leggott writes, 'the types of location typically posited in the British social realist text as sites of either transitory escape or sexual experimentation: a seaside resort, a funfair and a Butlins-style holiday camp' (ibid.: 96). This narrative provides ample opportunities for the display of mid-century style (indeed, the film was shot in 1950s time-warp locations on the Isle of Wight), particularly the iconography of US-inflected popular culture such as amusement arcades and dodgems. Fifties-ness is further signalled simultaneously with Essex's textual status as the star-playing-ordinary-bloke - by dressing Jim in a cheap copy of James Dean's red bomber jacket from Rebel Without A Cause (1955): in one shot, as Jim queues outside a cinema, Essex's face is briefly superimposed on the wall, in close-up and in profile, next to the image of the real James Dean on the poster for the film.

Attempting to clarify what distinguishes heritage cinema from the costume film styles or approaches that came before, Ginette Vincendeau suggests 'two at least equally important differences', one of which is that earlier costume dramas set their stories 'against a period backdrop, without bothering too much with fidelity', the other being that period films since the late 1970s are, Vincendeau contends, 'automatically mannerist and postmodern' (2001: xviii). However, That'll Be The Day is a more hybrid proposition than this. Its late-1950s mise-en-scène faithful enough not to distract the viewer with anachronisms, but - in marked contrasts with both Russell's self-conscious The Boy Friend and the commercial formula that EMI would shortly pursue in its Agatha Christie franchise - That'll Be The Day is not unduly concerned with this styling, and is equally lethargic in its approach to narrative action and character motivation.

For much of the film, Essex's Jim comes across as merely listless and motiveless rather than angry or interestingly enigmatic. In this, he has more in common with 1970s US cinema's drifting anti-protagonists such as Charlie (Harvey Keitel) in Martin Scorsese's Mean Streets (1973) than with the active, socially mobile rebels of the British New Wave. Jim 'progresses' merely to fairground sexual conquests, the rape of a schoolgirl, and a short-lived, unfaithful marriage, with his rise to equally flawed and alienated pop stardom saved for the sequel, Stardust. Despite Essex's own pro-filmic stardom, even Jim's supposed motivating passion for rock'n'roll is largely absent for much of That'll Be The Day, as is rock'n'roll itself. For the most part, the Ronco soundtrack is heard only faintly in the background, and diegetic live performance, when it arrives mid-way through the film, is tentative, via the holiday camp's house band (led by Billy Fury as the film's fictional Stormy Tempest) which 
specialises in Cliff Richard cover versions. When Jim asks: 'Ever thought to write your own songs?', the band's drummer (played by The Who's Keith Moon) replies listlessly: 'Nah, not really. Can't write. Anyway, you've got to be American to write rock'n'roll songs nowadays.' In tension with its retro elements, the film's emphasis on stasis and underachievement seems calculated to speak to Jim's state-school-educated counterparts in the 1970s present - Essex's core fanbase - more than to nostalgic pleasures, reserving its wistfulness for a past in which 'we', in Britain, were creative and literate and wrote our own songs.

All-star spectacle and 1920s-1930s high style: Lord Brabourne, Richard Goodwin, G. W. Films and the Agatha Christie franchise

From 1974 onwards, EMI's involvement in period film production took a more cohesive, and distinctly commercial, turn which would provide the company with its most profitable US release of the entire 1970s: the all-star Agatha Christie adaptation Murder on the Orient Express (1974). Made on a reported $£ 1.5$ million budget, the film grossed $\$ 19.1$ million in the US during the 1970s and more than \$27.6million in the US and Canada during its lifetime, along with high cinema admissions across a number of European countries. Under Cohen's leadership, EMI also profitably distributed Monty Python and the Holy Grail (1975). However, throughout the second half of the 1970s and into the 1980s, it was the big-spectacle period Christie formula which became the dominant mode, and the relationship with Lord Brabourne and Richard Goodwin's company G. W. Films (and, for one production, Brabourne's Mersham Productions) which became the dominant force in EMI's later years of period film production. Together they produced all four 1974-82 Christie films, followed in 1984 by David Lean's directorial swansong adaptation of E. M. Forster's A Passage to India.

Although the Christie franchise began, and enjoyed its greatest success, under Cohen's leadership at EMI, its persistence during the Deeley and Spikings era (1976-9) and Spikings's solo stint (1979-83) was a clear fit with the latter's focus on the international market and, increasingly, on the production of US rather than British films. These US EMI projects included further period films, notably Peter Bogdanovich's Nickelodeon (1976), set in 1911 Chicago in the milieu of early moving pictures, and two collaborations with Brooksfilms: David Lynch's culturally British The Elephant Man (1980), set in late nineteenth-century Whitechapel, and - from The Elephant Man's co-screenwriters, Christopher De Vore and Eric Bergren - Frances (1982), the 1920s Hollywood biopic of Frances Farmer. Such projects 
attest to American cinema's continuing fascination with retro subjects and styles into the 1980s, following earlier, high-profile iterations such as The Great Gatsby (1974).

This long-1970s vogue, in American cinema and beyond, for 1920s and 1930s Jazz Age, Art Deco and Prohibition-era styles is, I would suggest, highly relevant to the production context and hybrid commercial logic of EMI's highly stylised, luxuriously production- and costume-designed Christie films. As Street notes, even the first film in the Christie 'heritage crime' cycle, Murder on the Orient Express, although registered as British, was already a significantly American production: 'The director, Sidney Lumet, was American, as were cast members Lauren Bacall and Anthony Perkins; it was co-funded by Paramount and distributed by [them] in the USA, Canada and Japan' (2008: 110). The full star line-up, transnational but strongly British, included Albert Finney as an unusually lively Poirot, Ingrid Bergman, Jacqueline Bisset, Sean Connery, John Gielgud, Wendy Hiller, Vanessa Redgrave, Rachel Roberts, Richard Widmark and Michael York. The film deployed them in 'an approach that wallowed in the appearance of its stars in often brief scenes that were designed to cover the sparseness of the novel's characterization' (ibid.) but also played with knowing wit on the performers' star personae.

Orient Express's particular effectiveness has been attributed to Lumet's authorship, including his signature visual style. This effectiveness was, however, decreasingly matched, including at the box office, in the three later EMI/G.W. period Christie films: Death on the Nile (1978), The Mirror Crack'd (1980) and Evil Under the Sun (1982). One key factor is that Orient Express's striking, imaginative and coherent Art Deco production and costume design (the work of Tony Walton, production designer of Russell's The Boy Friend), and its wider coherence of 'quality' production aesthetics achieved on a low budget, are not sustained throughout the cycle. As budgets rose and directors and creative personnel came and went, unity of style gave way to kitsch and camp - in production design, costume and, in Death on the Nile, excesses of 'exotic' location as well as performance.

In a further index of the franchise's loss of heritage care and quality, one of Orient Express's selling points as a quality film was its original orchestral soundtrack, which was composed by Richard Rodney Bennett, a veteran of the quality costume film whose earlier credits included original music for Lady Caroline Lamb and the non-EMI Nicholas and Alexandra. EMI's release of film soundtrack albums was, unsurprisingly, part of its strategy 
from the outset, from The Railway Children and The Tales of Beatrix Potter onwards. These releases were beautifully produced (the Lady Caroline Lamb album came with detailed sleeve notes on the compositions and included bonus music cut from the released film), and such a success that EMI capitalised further by releasing two-film albums (anachronistically, the Orient Express soundtrack was paired with Lamb). Death on the Nile, on a significantly higher budget of \$7.9million, boasted cinematography by Jack Cardiff, a Nino Rota soundtrack and costumes by Anthony Powell, who would return for the fourth film, Evil Under the Sun. However, its director John Guillermin - of The Towering Inferno (1974) and King Kong (1976) fame - had presumably been hired for his experience with large casts and big spectacle rather than aesthetic sensitivity, and the result is both visually overblown boasting a tourist trail of Egyptian antiquities - and crassly orientalist in its racial representations. Guillermin's involvement highlights, moreover, that the ensemble-cast Christie formula was conceived precisely in order to try to compete in a transatlantic market dominated by 1970s genres such as the disaster movie. Indeed, Death on the Nile even features disaster movie (and, later, Naked Gun) regular George Kennedy as Andrew Pennington, a US lawyer who is embezzling the heiress Linnet Ridgeway Doyle (Lois Chiles); while the casting of Mia Farrow alongside Chiles raids - and ironises - their dual casting in The Great Gatsby a few years earlier.

As such details suggest, EMI's Christie spectaculars were, increasingly, produced in and for a market context which problematises any attempt to claim them as examples of heritage cinema. In their textual approach, too, the later films lack the features deemed by scholars to distinguish the heritage film from earlier, and more vulgar, forms of period cinema: namely emotional restraint, a close relationship to 'English literary culture and ... canons of good taste' (Higson 2006: 92), or the 'careful display of historically accurate dress and décor, producing ... a "museum aesthetic" (Vincendeau 2001: xviii). Street classifies the 1974-82 Christie cycle as heritage crime on the grounds of 'the EMI formula of exotic locations, established stars in period costumes and all manner of sumptuous detail that, in classic "heritage" style, could be said to dominate the films' (2008: 110). However, she notes that 'these adaptations also display a degree of parody and excessive stylization of Christie that encourages performances very much based on a camp sensibility' (ibid.). It is precisely these camp excesses - at the level of production design, costume and performance - that, I would argue, confirm the Christie films as something other than heritage cinema. From Death on the Nile onwards, where Powell's luxurious, elaborate, '1930s' costumes for Farrow and 
former supermodel Chiles exude a notably 1970s retro glamour, the cycle's period style is, if anything, characterised by an excess of the sumptuous signification of luxury over authenticity.

Creators, craft and genres: EMI's legacies for the field of period film-making

However, the significance of the production partnership with Brabourne/Goodwin, and Brabourne's company G. W. Films, for EMI's period film successes extended beyond the 1974-82 Agatha Christie franchise. Indeed, the Brabourne-EMI collaboration constitutes the one common thread running throughout EMI's involvement in period film production. This partnership remained active across successive leadership regimes at EMI, from Forbes to Lambert. The Brabourne-EMI productions ranged, up to a point, across the period genre spectrum, and certainly across modes, from sincerity to camp. Most importantly, however, the EMI period films which come closest to the heritage film mode, and those which not only most closely anticipate the 1980s heritage film's distinctive features but also forged one of the key creative teams active in 1980s heritage film production, were all Brabourne and Goodwin projects.

Of course, Brabourne and Goodwin's final film for EMI, David Lean's A Passage to India, was and is widely regarded as one of the quintessential 1980s-1990s heritage literary adaptations, and also, quite arbitrarily, happened to be the first film released in the 1980s1990s cycle of big-screen costume adaptations of novels by the gay, anti-colonial, secular humanist E. M. Forster, as well as an exemplar of the concurrent 1980s wave of 'Raj revival' films and TV adaptations. (The Forster films glut, in which five of his six novels were adapted for cinema within less than a decade, originated in the financially motivated decision by the Trustees of Forster's Literary Estate - King's College Cambridge - to put the film rights to his novels on the market around a decade after his death.) If approached instead from the angle of Lean's oeuvre and Brabourne and Goodwin's previous productions for EMI, however, A Passage to India is clearly as hybrid a project as the big-spectacle Christie films. Made on a vastly higher budget than the Merchant Ivory Productions Forster adaptations \$16million, compared to the $£ 2.25$ million, $£ 1.5$ million and \$8million budgets of Ivory’s $A$ Room With A View (1985), Maurice (1987) and Howards End (1992) respectively - Lean's film owes as much to the conventions of the historical or colonial epic as to heritage literary adaptation, and not merely because it departs from the typically intimate scale of the latter. 
The film is heritage in terms of historically and culturally accurate standards of dress and décor and its nominal fidelity to the literary source. However, rather than adapting the novel, Lean made unsanctioned changes to an existing script by Santha Rama Rau, the Indian-born female author of a highly successful 1957 stage version of A Passage to India which Forster had approved during his lifetime (and which had already been adapted for television as a 1965 BBC Play of the Month, directed by Waris Hussein). And, among Forsterians, Lean's treatment of "the great anti-colonial statement in English fiction in the first half of the twentieth century [by] the great debunker of imperial pomposity' (Morey 2007: 254) was and is widely disliked, viewed as a bowdlerised, sanitised betrayal of Forster's anti-English, antiRaj views, and variously guilty of colonial stereotyping, heterosexualisation and the brownface casting of Alec Guinness as Professor Goldbole. (See, for example, Hitchens 1985; Levine 1986.)

However, the seeds of 1980s heritage cinema in Brabourne and Goodwin's EMI output can be traced back much earlier, and found in a far quirkier, more personal and less well-remembered project: the 1971 live-action ballet film The Tales of Beatrix Potter. As the anonymously authored sleeve notes for EMI Records's 1971 release of the soundtrack album explained:

This is Richard Goodwin's first film as a fully-fledged producer and with it he renews a long-term working association with Lord Brabourne. This partnership was most recently re-established [while working together on Franco] Zeffirelli's Romeo and Juliet, when [sic] the ideas for their work for Tales of Beatrix Potter were formulated.

As is evident from the sleeve notes and other sources, The Tales of Beatrix Potter was a painstaking labour of love which, with genuine originality, drew together several levels of English cultural heritage and artistic disciplines at a high level of craft. The film brought to life the beloved rural animal characters from the children's storybooks created by writerillustrator Beatrix Potter - not as animation, but as a full ballet conceived for cinema. Stars of London's Royal Ballet perform in full Victorian costume, with naturalistic animal-head masks, either on hugely scaled-up sets (so that the dancers really do appear to be the size of mice) or ingeniously presented as if dancing in real Lake District landscapes. The film's exacting attention to detail included the preparation of a 'sketchbook-screenplay'; the composition of a new full ballet score by the Royal Ballet's Director of Music, John Lanchbery, 'using Victorian themes of the period'; choreography by the veteran Sir Frederick 
Ashton, who also appears in the film as Mrs Tiggywinkle; and designs for the animals 'adapted ... to reproduce exactly the Beatrix Potter sketches', with Rostislav Doboujinsky 'faithfully reproducing the heads in mask' [sic], according to the sleeve notes.

Doboujinsky, born in St Petersburg in 1903, was a theatrical costume and set designer whose specialisms included such whole-head masks. More significantly for the 1980s future of heritage-film craft, however, a few years earlier Goodwin had married a younger set and costume designer named Christine Edzard (born in Paris to German and Polish artist parents) who had trained with Doboujinsky. The Tales of Beatrix Potter originated in Goodwin and Edzard's interest in how they might 'devise a story presented in entirely visual terms'. The pair are credited as co-screenwriters, but it was Edzard who 'adapted' the animal designs in order to 'reproduce exactly' Potter's sketches for the film (as the sleeve notes explain); and her costume design and art direction won her two 1972 BAFTA nominations, alongside John Furniss and Carmen Dillon respectively for The Go-Between. (Both awards went to Visconti's Death in Venice [1971].) By 1975, Goodwin and Edzard had founded the company Sands Films, for which Edzard would script, direct and design the two post-1980 heritage films most renowned - and famously denounced by Raphael Samuel (1994) - for their highly meticulous, picturesque, period mise-en-scène: Little Dorrit (1987), adapted from Charles Dickens with a running time of almost six hours, and The Fool (1990), which drew upon the Victorian journalist Henry Mayhew's interviews collected in London Labour and the London Poor (1851).

To proceed to more general conclusions, EMI Films during the 1970s can be seen to have contributed to the development of 'pre-heritage' British period cinema (in both the temporal and textual senses) across a range of genre forms - both established and new - and hybrids. For the most part, these engagements with period film production were tangibly inflected - but in plural and varying ways - by EMI's priorities, perceptions and positioning as an expressly commercial company. The main generic areas can be summarised as follows:

1. The proto-heritage films of the Forbes era with late-Victorian or early-Edwardian settings: The Railway Children, The Go-Between and The Tales of Beatrix Potter. These films, even The Go-Between, were, however, marketed by EMI as 'family' rather than costume entertainment, reflecting a peculiarly 1970s context in which this classification centrally denoted a lack of violence or salaciousness (Moody 2018: 27). 2. The exercises in 1920s and 1930s style, beginning with the formalist, self- 
conscious, highly authored Art Deco experimentation, and box-office failure, of Russell's The Boy Friend, and subsequently rolled out, initially with great commercial success, in the four Agatha Christie all-star vehicles: Murder on the Orient Express, Death on the Nile, The Mirror Crack'd and Evil Under the Sun. This field of activity illustrates the shift from EMI's early, fleeting, limited support for any form of auteur cinema to the development of an internationally marketable franchise, and from high style to high camp and self-parody. Culturally, it also alerts us to a wider phenomenon: the long-1970s rise, and then mainstreaming, of 'a popular thirst for the recovery of earlier, and yet still modern, periods at an ever-accelerating rate' (Guffey 2006: 8).

3. The established historical film/historical romance genres. Here, EMI's involvement was limited to production of the TV spin-off Henry VIII and His Six Wives, and distribution of the more commercially successful Lady Caroline Lamb, the latter an unusual example of 1970s British involvement in European co-production.

4. One early prototypical genre hybrid which anticipates later developments in the British pop-culture retro or nostalgia film: That'll Be the Day.

In short, while proto-heritage-film tendencies are discernible within certain areas of EMI's period film output, these represent merely one strand within a generic diversity which also encompassed 1970s iterations of the traditional historical film; the more distinct, decadespecific, mania for 1920s-1930s vintage style; and, closely connected to this, a further embryonic period genre, or mode, which (like the heritage film) would escalate in prominence from the 1980s: the retro film, in which a heritage attentiveness to visual and material detail and style is applied to the recovery of modern, twentieth-century, pasts, as in the Christie franchise.

In contrast with the later heritage film, however, what emerges cumulatively from the detail of EMI's period film projects throughout the 1970s is that the company's corporate, studio-system organisational and business model was fundamentally antithetical to the forms of personal enthusiasm, personal passions and genuine creative collaboration which would typically shape the most popular and critically acclaimed successes of post-1979 heritage cinema. EMI's handling of its early proto-heritage film projects allowed a certain amount of space for personal vision (The Go-Between, The Tales of Beatrix Potter), but subjected the films to inadequate or tone-deaf marketing. EMI's approach regarding the Christie cycle, and 
to an extent Lean's approach in A Passage to India, demonstrated high craft values but applied these in the service of formulaic assemblage and touristic spectacle, and their all-star casts were similarly assembled as attractions for display. On A Passage to India, Lean's autocratic disrespect towards several of his leading actors (including Victor Banerjee as Dr Aziz, Peggy Ashcroft as Mrs Moore, and especially Judy Davis as Adela Quested) including on fundamental matters of character and textual interpretation - provoked levels of conflict that 'threatened to jeopardize successful completion of the film' (Richard Goodwin quoted in Ingersoll 2012: 43). Such attitudes and practices, and their underlying, dying production model, stood in instructive contrast to the genuinely collaborative ethos - rooted in a fundamental respect for both actors and authors, 'a strong belief in what they were doing and how they wanted to do it [and] ... a real faith in the people they worked with' (Jury 2006) - which shaped the three Merchant Ivory heritage Forster adaptations to more successful effect than Lean's.

\section{References}

Anon. (1973), 'Henry VIII and His Six Wives', Variety, 3 October, p. 15.

Bragg, T. (2015), 'History's drama: narrative space in "Golden Age” British television drama', in J. Leggott and J. A. Taddeo (eds), Upstairs and Downstairs: British Costume Drama Television from The Forsythe Saga to Downton Abbey, Lanham, MA: Rowman \& Littlefield, pp. 23-36.

Chapman, J. (2005), Past and Present: National Identity and the British Historical Film, London: I. B. Tauris.

Chapman, J. (2009), 'The watershed: Lawrence of Arabia (1962)', in J. Chapman and N. J. Cull (eds), Projecting Empire: Imperialism and Popular Cinema, London: I. B. Tauris. pp. 87-111.

Cook, P. (1996), Fashioning the Nation: Costume and Identity in British Cinema, London: British Film Institute.

Elsaesser, T. (2006), 'Images for sale: the "new” British cinema', in L. Friedman (ed.), Fires Were Started: British Cinema and Thatcherism, $2^{\text {nd }}$ edn, London: Wallflower, pp. 4557.

Forster, L. and Harper, S. (2010), 'Introduction', in L. Forster and S. Harper (eds), British Culture and Society in the 1970s: The Lost Decade, Newcastle-upon-Tyne: Cambridge Scholars Press.

Fuller, G. (1988), 'Battle for Britain', Film Comment, 24: 4, July/August, pp. 62-8. 
Garvey, A. (2010), 'The Boy Friend: Ken Russell's "anti-musical”, in L. Forster and S.

Harper (eds), British Culture and Society in the 1970s: The Lost Decade, pp. 225-34.

Garvey, A. (2010), “Pre-sold to millions”: the sitcom film of the 1970s', in P. Newland (ed.),

Don't Look Now: British Cinema in the 1970s, Bristol: Intellect, pp. 177-86.

Guffey, E. (2006), Retro: The Culture of Revival, London: Reaktion Books.

Hall, S. (2002), 'Monkey feathers: defending Zulu', in C. Monk and A. Sargeant (eds), British Historical Cinema: The History, Heritage and Costume Film, London: Routledge, pp. 110-28.

Harper, S. (1994) Picturing the Past: The Rise and Fall of the British Costume Film, London: British Film Institute.

Harper, S. and Smith, J. (eds) (2013), British Film Culture in the 1970s: The Boundaries of Pleasure, Edinburgh: Edinburgh University Press.

Hartley, L. P. (1953), The Go-Between, London: Hamish Hamilton.

'Hawk.' (1972a), 'Henry VII and His Six Wives', Variety, 4 August, p. 24.

'Hawk.' (1972b), 'Lady Caroline Lamb', Variety, 29 November, p. 26.

Hewison, R. (1987), The Heritage Industry: Britain in a Climate of Decline, London: Methuen.

Higson, A. (2006), 'Re-presenting the national past: nostalgia and pastiche in the heritage film', in L. Friedman (ed.), Fires Were Started: British Cinema and Thatcherism, $2^{\text {nd }}$ edn, London: Wallflower, pp. 91-109.

Higson, A. (1996), 'The heritage film and British cinema', in A. Higson (ed.), Dissolving Views: Key Writings on British Cinema, London: Cassell, pp. 232-48.

Hitchens, C. (1985), 'Busted blue: A Passage to India', Grand Street, 4, Spring, pp. 215-17. Ingersoll, E. G. (2012), Filming Forster: The Challenges in Adapting E. M. Forster's Novels for the Screen, Madison \& Teaneck, NJ: Fairleigh Dickinson University Press.

Jury, L. (2006), 'James Ivory: a death in the family', Independent, 24 March, available at https://www.independent.co.uk/arts-entertainment/films/features/james-ivory-a-deathin-the-family-6105738.html. [Accessed 19 August 2020]

Leggott, J. (2008), 'Nothing to do around here: British realist cinema in the 1970s', in R. Shail (ed.), Seventies British Cinema, London: British Film Institute, pp. 94-104.

Levine, J. P. (1986), 'Passage to the Odeon: too Lean', Literature/Film Quarterly, 14, pp. $139-50$.

Melly, G. (1972), ‘Screams and swoons', Observer, 26 November, p. 34.

Monk, C. (1995/2001), 'Sexuality and heritage', Sight and Sound, 5: 10, October 1995, pp. 
32-4. Republished in G. Vincendeau (ed.) (2001), Film/Literature/Heritage: A Sight and Sound Reader (London: British Film Institute), pp. 6-11.

Monk, C. (2002), 'The British heritage-film debate revisited', in C. Monk and A. Sargeant (eds), British Historical Cinema: The History, Heritage and Costume Film, London: Routledge, pp. 176-98.

Monk, C. (2011), Heritage Film Audiences: Period Films and Contemporary Audiences in the UK, Edinburgh: Edinburgh University Press.

Monk, C. (2015), 'Pageantry and populism, democratization and dissent: the forgotten 1970s', in J. Leggott and J. A. Taddeo (eds) Upstairs and Downstairs: British Costume Drama Television from The Forsyte Saga to Downton Abbey, Lanham, MD: Rowman \& Littlefield, pp. 3-21.

Moody, P. (2018), EMI Films and the Limits of British Cinema, Basingstoke: Palgrave Macmillan.

Morey, P. (2007), 'Postcolonial Forster', in D. Bradshaw (ed.), The Cambridge Companion to E. M. Forster, Cambridge: Cambridge University Press, pp. 254-73.

Newland, P. (ed.) (2010), Don't Look Now: British Cinema in the 1970s, Bristol: Intellect. Samuel, R. (1989), 'Docklands Dickens', in R. Samuel (ed) Patriotism: The Making and Unmaking of National Identity, Volume III: National Fictions, London: Routledge, pp. 275-86.

Sargeant, A. (2005), British Cinema: A Critical History, London: British Film Institute. Seligman, D. (1972), 'All star history show', Gay News, 18 December, p. 17.

Shail, R. (ed.) (2008), Seventies British Cinema, London: British Film Institute.

Smith, J. (2008), 'Glam, spam and Uncle Sam: funding diversity in 1970s British film production', in R. Shail (ed.), Seventies British Cinema, London: British Film Institute, pp. 67-80.

Smith, J. (2013), 'Cinema statistics, box office and related data', in S. Harper and J. Smith (eds), British Film Culture in the 1970s: The Boundaries of Pleasure, Edinburgh: Edinburgh University Press, pp. 261-74.

Sprengler, C. (2009), Screening Nostalgia: Populuxe Props and Technicolor Aesthetics in Contemporary American Film, Oxford: Berghahn Books.

Street, S. (2008), 'Heritage crime: the case of Agatha Christie', in R. Shail (ed.), Seventies British Cinema, London: British Film Institute, pp. 105-16.

Van Eecke, C. (2015), Pandaemonium: Ken Russell's Artist Biographies as Baroque Performance, Maastricht: Universitaire Pers Maastricht. 
Vidal, B. (2012), Heritage Film: Nation, Genre and Representation, London: Wallflower. Vincendeau, G. (2001), 'Introduction', in G. Vincendeau (ed.) Film/Literature/Heritage: A Sight and Sound Reader, London: British Film Institute, pp. xi-xxvi.

Williams, M. (2016), David Lean, Manchester: Manchester University Press.

Wright, P. (1985), On Living in an Old Country: The National Past in Contemporary Britain, London: Verso.

Claire Monk is Professor of Film \& Film Culture at De Montfort University, where she is a founding member of DMU's Cinema and Television History Institute (CATHI) and Centre for Adaptations. She has been called a 'leading proponent' in the debates around heritage cinema and is known for introducing gender and sexuality, audience reception and fan/digital participatory practices into discussion of heritage film. Publications include British Historical Cinema, co-edited with Amy Sargeant (Routledge 2002), the monograph Heritage Film Audiences (EUP 2011), 'Heritage Film Audiences 2.0' (2011) for Participations, 'From "English" heritage to transnational audiences' in Cooke and Stone (eds) Screening European Heritage (Palgrave Macmillan 2016) and, recently, 'Maurice without ending: from Forster's palimpsest to fan-text' for the centenary collection Tsai \& Sutton (eds) Twenty-First-Century Readings of E. M. Forster's Maurice (Liverpool University Press 2020). The BFI's 2019 UK Blu-ray premiere release of James Ivory's 1987 gay classic Maurice, adapted from Forster, features her audio commentary, acclaimed by The Arts Desk as 'revelatory'. 